\begin{tabular}{c} 
PEDIOMATERNAL \\
NURSING JOURNAL \\
Vol. 5, No. 2, September 2019 \\
Journal Homepage: https://e-journal.unair.ac.id/PMNJ// \\
\hline
\end{tabular}

Original Research

\title{
The Analysis of Related Factors of Cervical Cancer Prevention Behavior in Reproductive-Aged Women
}

\author{
Adilla Kusuma Dewi, Mira Triharini, and Tiyas Kusumaningrum \\ Faculty of Nursing, Universitas Airlangga, Surabaya, Indonesia
}

\section{ARTICLE HISTORY}

Received: May 27, 2019

Accepted: July 23, 2019

\section{KEYWORDS}

cervical cancer; interpersonal factors; perceived barriers; selfefficacy; reproductive-aged women

\section{CORRESPONDING AUTHOR}

Adilla Kusuma Dewi adilla.kusuma.dewi2015@fkp.unair.ac.id

Faculty of Nursing, Universitas Airlangga, Surabaya, Indonesia

Cite this as:

\begin{abstract}
Introduction: Cervical cancer is a disease which can causes and increase infertility, morbidity and mortality of women in the world. The incidence rates of cervical cancer can be reduced by doing primary and secondary preventions. This study aims to determine the relation of self-efficacy, perceived barriers and interpersonal factors to cervical cancer prevention behavior in reproductive-aged women.

Methods: The study design was cross sectional. The population were married women of reproductive-age between 15-45 years old in Pacarkeling community health center, Surabaya. The sample of this study was 110 respondents which used cluster sampling technique. The independent variables were perceived barriers, self-efficacy and interpersonal factors and the independent variable was cervical cancer prevention behavior. The data analyzed by using spearman rho statistical test with a significance level of $\alpha \leq 0.05$.
\end{abstract}

Results: The results of this study shows that the perceived barriers $(p=0,000 r=0,562)$ and interpersonal factors ( $p=0,001 r=0,314)$ were related to cervical cancer prevention behavior, however self-efficacy was not related to cervical cancer prevention behavior ( $\mathrm{p}$ $=0,668 \mathrm{r}=0,041)$.

Conclusion: Perceived barriers in women of childbearing age who are negative will hinder cervical cancer prevention behavior. The higher the interpersonal factors, the better the behavior of reproductive-aged women in cervical cancer prevention. Perceived barriers and interpersonal factors can determine cervical cancer prevention behavior in women of childbearing age. Self-efficacy was not been proven to determine cervical cancer prevention behavior.

Dewi, A, K., Triharini, M., \& Kusumaningrum, T. (2019). The Analysis of Related Factors of Cervical Cancer Prevention Behavior in Reproductive-Aged Women. Pediomaternal Nurs. J., 5(2), 197-205

\section{INTRODUCTION}

Cervical cancer is a disease that can be prevented. The Indonesian government already has a program of early detection of cervical cancer since 2008 (1). The program has been included in the financing of national health insurance or known as national health coverage. There is an effect of barriers perceptions to the use of HPV vaccines and statistically not significant (2). The barriers perception perceived by reproductive-aged women is the reason of reproductive-aged women do not do any AVI (acetic acid visual inspection) tests and the lack of support of husband is the factor that weakens the occurrence of IVA test (3). Self-efficacy is not related to cervical cancer prevention behavior (4). The higher of selfefficacy makes the knowledge about pap smears and cervical cancer also increases (5). There is no relationship between husband's support and early detection of cervical cancer. The active role of cadres can be influence a woman to do early detection of cervical cancer (6). According to that case, there are no previous study which shown a consistent relationship between perceived barrier, self-efficacy, and interpersonal factors with cervical cancer prevention behavior, both prevention through AVI tests, pap smears or other prevention.

Based on Global Cancer Observatory (GCO) data in 2018, there are 32.469 new cases of cervical cancer in all ages and 18.879 mortality cases of cervical 
cancer throughout the world (7). According to WHO, cervical cancer is the most common cancer in women with an estimated 570,000 new cases in 2018 which represents $6.6 \%$ of all women cancers cases (8). The estimated number of cervical cancer cases in Indonesia in 2013 was 98,692 and East Java Province becomes the largest contributor to this case with 21,313 cases (1).

There are most of reproductive-aged women who did not do any AVI test because they do not feel any symptoms of cervical cancer, they never received an AVI test socialization, the husbands do not understand and do not support the test, and their friends also did not do any AVI test (3). The reproductive-aged women who have weak selfefficacy will influence the primary and secondary prevention of cervical cancer (4). The health about cervical cancer is affected by the accessibility of information sources such as reading, parents and friends counseling about the importance of early detection of cervical cancer (9). Cervical cancer can cause and increase infertility, morbidity and mortality in women, therefore the efforts of cervical cancer prevention is very important to control and prevent the increasing cases (10).

The government appealed some regulations to prevent cancer by implementing CERDIK behavior which are do health checks periodically, do not smoke, do physical activity, do a healthy diet with balanced calories, do enough rest and manage stress (11). The Health Promotion Model theory explains a person's behavior is determined by specific cognitive behavioral factors and attitudes that produce the end result of health promotion behavior, so this theory can be used to analyze the related factors to cervical cancer prevention behavior (12). The aim of the study is to analyze relationship between perceived barriers, self-efficacy and interpersonal factors with cervical cancer prevention behavior in reproductive-aged women.

\section{METHOD}

\subsection{Design}

The design used correlational with cross-sectional approach. Cross-sectional research is a type of research which emphasizes the measurement of independent and dependent variables which held once at a time (12).

\subsection{Population, Samples, and Sampling}

The population in this study were reproductive-aged women in the Pacarkembang district, Pacarkeling community health center Surabaya. The sample in this study was 110 married women of reproductive age between 15-49 years old, able to read and write. The sampling technique used was cluster sampling type probability sampling technique.

Table 1. Demographic Data Characteristics of Reproductive-Aged Women in the Working Area of the Pacarkeling Community Health Center, May $2019(n=110)$

\begin{tabular}{|c|c|c|}
\hline Characteristics & $\mathbf{n}$ & $\%$ \\
\hline \multicolumn{3}{|l|}{ Age } \\
\hline 17-25 Years & 11 & 10 \\
\hline 26-35 Years & 44 & 40 \\
\hline 36-45 Years & 27 & 24.5 \\
\hline 46-49 Years & 28 & 25.5 \\
\hline \multicolumn{3}{|l|}{ Education } \\
\hline Not finished & 1 & 0.9 \\
\hline Elementary School & 10 & 9.1 \\
\hline Junior High School & 25 & 22.7 \\
\hline Senior High School & 56 & 50.9 \\
\hline Higher Education & 18 & 16.4 \\
\hline \multicolumn{3}{|l|}{ Occupation } \\
\hline Private employees & 25 & 22.7 \\
\hline Labor & 3 & 2.7 \\
\hline Trader & 19 & 17.3 \\
\hline Housewife & 63 & 57.3 \\
\hline \multicolumn{3}{|l|}{ Family Income } \\
\hline$\leq$ Regional wage $\operatorname{Rp} 3,871,000$ & 76 & 69.1 \\
\hline$>$ Regional wage $\operatorname{Rp} 3,871,000$ & 34 & 30.9 \\
\hline \multicolumn{3}{|l|}{ Parity } \\
\hline 0 & 4 & 3.6 \\
\hline 1 & 17 & 15.5 \\
\hline 2 & 50 & 45.5 \\
\hline 3 & 27 & 24.5 \\
\hline 4 & 6 & 5.5 \\
\hline 5 & 4 & 3.6 \\
\hline 6 & 2 & 1.8 \\
\hline
\end{tabular}




\subsection{Variables}

The independent variable is a variable that influences or its value determines other variables (12). The independent variables in this study were perceived barriers, self-efficacy and interpersonal factors. In the other hand, the dependent variable is the factor which is observed and measured to determine whether there is a relationship or influence of the independent variable (12). The dependent variable in this study was the behavior of cervical cancer prevention in reproductive-aged women.

\subsection{Instruments}

The instrument used in this study was a questionnaire which consist of demographic data, perceived barriers, self efficacy, interpersonal factors and cervical cancer prevention behaviors. The demographic data questionnaire consisted of the current age of reproductive-aged women, recent education, occupation, family income, parity, history of contraception, first sexual intercourse age, sources of information about cervical cancer, AVI examination or pap smears for the prevention of cervical cancer and vaccines HPV.

The perceived barriers questionnaire was modified from the previous studies (13) which had tested for validity and reliability with $r$ table $=0.514$, $\mathrm{r}$ count $=0.547-0.716$ and alpha cronbach amounted to 0.917 . The assessment used a Likinal scale design Likert measurement, consisted of 14 questions with 3 parameters, those are obstacles, barriers and personal costs.

The self-efficacy questionnaire was modified from the previous studies (4) which had tested for validity and reliability with $\mathrm{r}$ table $=0.514, \mathrm{r}$ count $=$ 0.657-0.916 and alpha cronbach amounted to 0.931. The assessment was measured by a Likinal scale design of Likert measurement, consisted of 7 questions with three parameters, those are cervical cancer prevention beliefs, information obtained, and efforts to prevent cervical cancer.

Interpersonal factor questionnaire was taken from previous studies (14) which had tested for validity and reliability with $\mathrm{r}$ table $=0.396, \mathrm{r}$ count $=$ 0.403-0.841 and alpha cronbach 0.884. The assessment was measured by the Guttman measurement design ordinal scale, consisted of 12 questions with 3 parameters, those are encouragement or advice related to cervical cancer prevention, social support and the influence of other people in preventing cervical cancer.

The cervical cancer prevention behavior questionnaire was modified from previous studies (4) which had tested for validity and reliability with $\mathrm{r}$ table $=0.514, r$ count $=0.527-0.806$ and alpha cronbach amounted to alpha cronbach amounted to 0.879. Assessment was measured with a Likinal scale design Likert measurement consisted of 7 questions with 6 parameters, those are do health checks periodically, do not smoke, do physical activity, do a healthy diet with balanced calories, do enough rest and manage stress.

\subsection{Procedure}

The study was conducted in Pacarkeling Community Health Center, Pacarkembang, Surabaya on May 1427 2019. The retrieval and data collection conducted with help by the midwives and cadres in each area. The data collection was carried out at Maternal and Child Health Services and collecting reproductiveaged women at the cadre's home.

Data collection at the Maternal and Child Health Services was conducted before the weighing activity, however, the data collection which held the cadre's house was conducted when all of the mothers came to the gather places, then the researchers introduced themselves and explained the purpose and procedures of the data collection of the study and asked for approval from the respondents. Respondents who agreed were given an informed consent sheet to be signed. The researchers gave the questionnaire sheets and provide the instructions to fill the questionnaire to the respondents.

The questionnaire was filled based on the conditions of the respondents. During the questionnaire filling process the researchers stayed near the respondents and assisted the respondents to give information if the respondents did not understand about the questions on the questionnaire until the questionnaire filling process was completed. After completing the questionnaire sheets, the questionnaire was returned to the researchers to be checked weather the questionnaire all filled or not. After all of the questionnaire was filled out, the researcher gives souvenirs and leaflets to the respondents as a form of gratitude for the respondents' participation.

\subsection{Data Analysis}

The data analysis used in this study was Spearman Rho statistical test with the significance level $\alpha \leq 0.05$. The degree of strength relationship between variables was measured by the correlation coefficient (r). All statistical data measurements were performed using SPSS 21. Spearman Rho statistical test aims to determine the related variables with cervical cancer prevention behavior in reproductive-aged women.

\subsection{Ethical Clearance}

This study was conducted in accordance with research ethics including informed consent, anonymity and confidentiality. This research was conducted an ethics test at Faculty of Nursing health research ethics commission Airlangga University with number: 1397-KEPK on May 13, 2019.

\section{RESULT}

Based on the characteristics demographic data most of reproductive-aged women in the range of 26-35 years old as many as 44 reproductive-aged women (40\%). Senior high school was the most recent 
Table 2. Reproduction History Data of Reproductive-Aged Women in the Working Area of the Pacarkeling Community Health Center, May $2019(n=110)$

\begin{tabular}{|c|c|c|}
\hline Characteristics & $\mathbf{n}$ & $\%$ \\
\hline \multicolumn{3}{|l|}{ Use of contraception } \\
\hline Pills & 17 & 15.5 \\
\hline Injection & 30 & 27.3 \\
\hline Implant & 5 & 4.5 \\
\hline IUD/Spiral & 22 & 20 \\
\hline Not using any contraception & 29 & 26.4 \\
\hline Sterile & 5 & 4.5 \\
\hline Condom & 2 & 1.8 \\
\hline \multicolumn{3}{|l|}{ The age of first sexual intercourse } \\
\hline$\leq 18$ years old & 31 & 28.2 \\
\hline$>18$ years old & 79 & 71.8 \\
\hline \multicolumn{3}{|l|}{ Resources } \\
\hline Health workers & 91 & 82.7 \\
\hline Family & 10 & 9.1 \\
\hline Friends of the same age & 4 & 3.6 \\
\hline Print / electronic media & 5 & 4.5 \\
\hline \multicolumn{3}{|l|}{ Pap Smear Examination/ AVI test } \\
\hline Not yet & 59 & 53.6 \\
\hline Ever & 51 & 46.4 \\
\hline \multicolumn{3}{|l|}{ HPV Vaccine } \\
\hline Not yet & 105 & 95.5 \\
\hline Ever & 5 & 4.5 \\
\hline
\end{tabular}

education as many as 56 of reproductive-aged women $(50.9 \%)$. Most of the reproductive-aged women were housewives as many as 63 of reproductive-aged women $(57.3 \%)$. Monthly family income was mostly Rp. 3,871,000 as many as 76 of reproductive-aged women (69.1\%). Most of the reproductive-aged women had been pregnant twice as many as 50 reproductive-aged women (45.5\%). The most used of contraception was the type of injectable contraception as many as 30 reproductive-aged women $(27.3 \%)$. The age of first sexual intercourse $>18$ years old as many as 79 reproductive-aged women $(71.8 \%)$. The source of information about cervical cancer was mostly from health workers as many as 91 reproductive-aged women (82.7\%). There were 51 reproductive-aged women (46.4\%) who had a Pap smear or AVI while a total of 59 reproductive-aged women (53.6\%) had never had a Pap smear or AVI. Most of the reproductive-aged women had not yet carried out the HPV vaccine as many as 105 reproductive-aged women (95.5\%) and only 5 reproductive-aged women (4.5\%) had already carried out the HPV vaccine.

Most reproductive-aged women have perceived barriers or positive barrier perceptions which reproductive-aged women were feel there are any obstacles to do a prevention of cervical cancer as many as 58 respondents (52.7\%), weak self-efficacy as many as 57 reproductive-aged women (51.8\%), a high interpersonal factor as many as 70 reproductiveaged women (63.6\%) and good cervical cancer prevention behaviors as many as 62 reproductiveaged women (56.4\%).

The statistical test results of the relationship between perceived barriers with cervical cancer prevention behavior using Spearman Rho obtained a significance value $(p)=0,000$ which means there was a relationship between perceived barriers with cervical cancer prevention behavior with a correlation coefficient $(r)=0.562$ which means it had a moderate strength relationship and positive direction relationship. Most of the reproductive-aged women as many as 48 reproductive-aged women (43.6\%) have positive perceived barriers or had obstacles to do cervical cancer prevention behavior and the cervical cancer prevention behavior was good.

The statistical test results of the relationship between self efficacy with cervical cancer prevention behavior using Spearman Rho obtained a significance value $(\mathrm{p})=0.668$ which means there was no relationship between self-efficacy with cervical cancer prevention behavior with a correlation coefficient $(\mathrm{r})=0.041$ which means it had a very low strength relationship and positive direction relationship. Most reproductive-aged women (31.2\%) had weak self-efficacy and good cervical cancer prevention behaviors.

The statistical test results of the relationship between interpersonal factors with cervical cancer prevention behavior using Spearman Rho obtained significance value $(p)=0.001$ which means there was a relationship between interpersonal factors with cervical cancer prevention behavior with a correlation coefficient $(r)=0.314$ which means it had a low strength relationship and positive direction relationship. Most of the reproductive-aged women, 47 of them $(42.7 \%)$ had high interpersonal factors and good cervical cancer prevention behaviors. 


\section{DISCUSSION}

4.1 Relationship between perceived barriers with cervical cancer prevention behavior

The results of this study shown a significant relationship between perceived barriers with cervical cancer prevention behavior in reproductive-aged women with moderate strength relationship and positive direction relationship. According to the Health Promotion Model theory, perceived barriers are perceptions of obstacles, the barriers, and personal costs which required to perform a healthy behavior (15). Perceived barriers were obstacles to the action which had to be taken. These obstacles were in the form of unavailability, insufficient, expensive, difficult or time spent from a main activity (12).

Most of reproductive-aged women had positive perceived barriers or feel the obstacles in preventing cervical cancer. It was because of the most reproductive-aged women aged 26-35 years were in the early adult category (16), based on demographic data, most reproductive-aged women were housewives and have 2 young children. WUS's working schedule or taking care of children and households became the obstacles to do not conduct the tests also increasing. The obstacle for reproductive-aged women in preventing cervical cancer were the uncomfortable or embarrassed feeling during an AVI or pap smear examination because they had to show and let other people to see check their vagina. It also supported by the beliefs of religious principles if genitals area cannot be seen by others (3).

The results of this study shown that most of reproductive-aged women had positive perceived barriers and have good cervical cancer prevention behavior. It was because reproductive-aged women have good behavioral control which caused by the support from their surroundings especially from health workers to prevent cervical cancer. The socialization of cervical cancer and AVI tests from the community health center made the individual of WUS to be encouraged to do AVI tests (3). Based on demographic data, most of reproductive-aged women got the information about cervical cancer from the health workers and most of reproductive-aged women were senior high school graduate (6).

Reproductive-aged women had negative perceptions or did not have barriers to cervical cancer prevention behavior and had less cervical cancer prevention behavior. It was because reproductive-aged women did not feel that they need to prevent cervical cancer because there were no symptoms of the disease, so they assumed that they do not need to do any AVI test or pap smear. Most of women were got married in the young ages but it did not make them to do any cervical cancer screening (CCS) until they reach a certain age or the symptoms appear (17).

In accordance with the research conducted by (18) lack of willingness was the most common reported perceived barriers to healthy eating (PBHE) by men and women, followed by healthy dietary costs for women and hedonists (did not like healthy food / healthy food was too boring) in men. For example, observing the healthy food was too expensive was the most frequently reported obstacle by women and men. However, men and women who reported this barrier did mean that they rarely or maybe consume fruit and vegetable (F\&V).

In the other hand, the other research conducted by (2) which stated that the majority of women faced many obstacles to do the HPV vaccine and they chose to do not do the HPV vaccine as a preventive measure against cervical cancer.

4.2 The relationship between self efficacy and cervical cancer prevention behavior

The results showed that there was no relation between self-efficacy and cervical cancer prevention behavior in reproductive-aged women with very low strength relationship and positive direction relationship. Self-efficacy motivated the health promotion behavior directly and indirectly by the obstacles and determined by the level of commitment and action plan (12).

Self-efficacy was an assessment of personal ability to do certain health behaviors, the self confidence in performing health behaviors properly (15). In this study shown the opposite result that selfefficacy was not significantly related to cervical cancer prevention behavior in reproductive-aged women. Self efficacy determined how people feel, think, motivate themselves and behave (19). Reproductive-aged women decided themselves to prevent cervical cancer and most reproductive-aged women have weak self efficacy. Reproductive-aged women who have weak self-efficacy will influence the primary and secondary prevention of cervical cancer (4).

In this study reproductive-aged women who have weak self efficacy were able to perform cervical cancer prevention behavior well. This was because the primary form of cervical cancer prevention includes many activities which carried out in daily life such as do physical activity, consume healthy food, avoid cigarette smoke, have a good rest, avoid stress, although less able to avoid foods containing 5P (flavoring, preservatives, dyes, artificial sweeteners and sweeteners) and had not yet done an AVI or pap smear examination. In accordance with demographic data, most of reproductive-aged women had not had an AVI or pap smear test and had never had an HPV vaccine. A higher purpose in life was associated with the greater health prevention. Psychological strength such as have a meaning and direction in life involved more than just being free from emotional stress (20). In addition, in this study several respondents were cadre mothers. Mothers who were close to the midwives or other health workers influenced the mother's decision to conduct an examination (21). 
Table 3. Relationship of Perceived Barriers with Cervical Cancer Prevention Behavior in Reproductive-Aged Women in The Working Area of the Pacarkeling Puskesmas, May 2019 (n=110)

\begin{tabular}{|c|c|c|c|c|c|c|}
\hline \multirow{3}{*}{ Perceived Barriers } & \multicolumn{4}{|c|}{ Cervical Cancer Prevention Behavior } & \multirow{2}{*}{\multicolumn{2}{|c|}{ Total }} \\
\hline & \multicolumn{2}{|c|}{ Less } & \multicolumn{2}{|c|}{ Good } & & \\
\hline & $\mathbf{n}$ & $\%$ & $\mathbf{n}$ & $\%$ & $\mathbf{n}$ & $\%$ \\
\hline Negative & 38 & 34.5 & 14 & 12.7 & 52 & 47.3 \\
\hline Positive & 10 & 9.1 & 48 & 43.6 & 58 & 52.7 \\
\hline Total & 48 & 43.6 & 62 & 56.4 & 110 & 100 \\
\hline Spearman rho $p=0.000 \mathrm{r}=0.562$ & & & & & & \\
\hline
\end{tabular}

Table 4. The Relationship of Self Efficacy with Cervical Cancer Prevention Behavior in Reproductive-Aged Women in The Working Area of the Pacarkeling Community Health Center, May 2019 (n=110)

\begin{tabular}{|c|c|c|c|c|c|c|}
\hline \multirow{3}{*}{ Self-Efficacy } & \multicolumn{4}{|c|}{ Cervical Cancer Prevention Behavior } & \multirow{2}{*}{\multicolumn{2}{|c|}{ Total }} \\
\hline & \multicolumn{2}{|c|}{ Less } & \multicolumn{2}{|c|}{ Good } & & \\
\hline & $\mathbf{n}$ & $\%$ & $\mathbf{n}$ & $\%$ & $\mathbf{n}$ & $\%$ \\
\hline Weak & 26 & 23.6 & 31 & 28.2 & 57 & 51.8 \\
\hline Strong & 22 & 20 & 31 & 28.2 & 53 & 48.2 \\
\hline Total & 48 & 43.6 & 62 & 56.4 & 110 & 100 \\
\hline Spearman rho $p=0.668 \mathrm{r}=0.041$ & & & & & & \\
\hline
\end{tabular}

Table 5. The Relationship of Interpersonal Factors with Cervical Cancer Prevention Behavior in ReproductiveAged Women in the Working Area of the Pacarkeling Community Health Center, May 2019 (n=110)

\begin{tabular}{|c|c|c|c|c|c|c|}
\hline \multirow{3}{*}{ Interpersonal Factor } & \multicolumn{4}{|c|}{ Cervical Cancer Prevention Behavior } & \multirow{2}{*}{\multicolumn{2}{|c|}{ Total }} \\
\hline & \multicolumn{2}{|c|}{ Less } & \multicolumn{2}{|c|}{ Good } & & \\
\hline & $\mathbf{n}$ & $\%$ & $\mathbf{n}$ & $\%$ & $\mathbf{n}$ & $\%$ \\
\hline Low & 15 & 13.6 & 5 & 4.5 & 20 & 18.2 \\
\hline Moderate & 10 & 9.1 & 10 & 9.1 & 20 & 18.2 \\
\hline High & 23 & 20.9 & 47 & 42.7 & 70 & 63.6 \\
\hline Total & 48 & 43.6 & 62 & 56.4 & 110 & 100 \\
\hline
\end{tabular}

Spearman rho $\mathrm{p}=0.001 \mathrm{r}=0.314$

Table 6. Relationship of Perceived Barriers, Self Efficacy, Interpersonal Factor with Cervical Cancer Prevention Behavior in Reproductive-Aged Women in the Working Area of The Pacarkeling Community Health Center, May $2019(n=110)$

\begin{tabular}{|c|c|c|c|c|c|c|c|c|}
\hline \multirow{3}{*}{ Factor } & & \multicolumn{4}{|c|}{ Cervical Cancer Prevention Behavior } & \multirow{2}{*}{\multicolumn{2}{|c|}{ Total }} & \multirow{3}{*}{ Statistic } \\
\hline & & \multicolumn{2}{|c|}{ Less } & \multicolumn{2}{|c|}{ Good } & & & \\
\hline & & $\mathbf{n}$ & $\%$ & $\mathbf{n}$ & $\%$ & $\Sigma$ & $\%$ & \\
\hline Perceived & Negative & 38 & 34.5 & 14 & 12.7 & 52 & 47.3 & $\mathrm{p}=0.000$ \\
\hline Barriers & Positive & 10 & 9.1 & 48 & 43.6 & 58 & 52.7 & $r=0.562$ \\
\hline \multirow[t]{2}{*}{ Self efficacy } & Weak & 26 & 23.6 & 31 & 28.2 & 57 & 51.8 & $\mathrm{p}=0.668$ \\
\hline & Strong & 22 & 20 & 31 & 28.2 & 53 & 48.2 & $r=0.041$ \\
\hline Interpersonal & Low & 15 & 13.6 & 5 & 4.5 & 20 & 18.2 & \multirow{3}{*}{$\begin{array}{l}\mathrm{p}=0.001 \\
\mathrm{r}=0.314\end{array}$} \\
\hline \multirow{2}{*}{ Factor } & Moderate & 10 & 9.1 & 10 & 9.1 & 20 & 18.2 & \\
\hline & High & 23 & 20.9 & 47 & 42.7 & 70 & 63.6 & \\
\hline
\end{tabular}

Reproductive-aged women had strong self efficacy and poor cervical cancer prevention behaviors. This was because most reproductive-aged women were senior high school graduates so they can made their own decisions to prevent cervical cancer and get information from their friends and people around them so they want to prevent cervical cancer prevention. Education can be influence someone in making decisions in early detection of cervical cancer. The higher their education, the better their knowledge and wiser in making decisions in the early detection of cervical cancer (6). The invitation of peers was enough to influence the decision of mothers to do the test, especially if the person who invites was a close friend, because usually mothers believe in stories from their peers. Many mothers finally decided to do an examination after they have been told by their friends and because their friends invite them to join the test.

The higher the self-efficacy of married women, the greater their awareness of the importance of early diagnosis (5). Reproductive-aged women were not afraid to do an AVI or pap smear, they also not afraid to know the results of an AVI or pap smear, and had good social support. However, they had obstacles which are embarrassed or uncomfortable when doing an AVI or pap smear test which made them did not do a AVI test or pap smear. This was the same as the demographic data of most reproductive-aged women who had not had an AVI or pap smear .

Most of reproductive-aged women used hormonal contraception, that is, inject contraception. 
Women suffering from cervical cancer by 3.36 times greater in women who used hormonal contraception pills and injections compared to implantable hormonal contraception (22). Then, if it done as an effort to prevent cervical cancer properly, it could be reducing the risk factors for cervical cancer. In this study some respondents were cadre mothers. Mothers who were close to the midwives or other health workers influence the mother's decision to conduct an examination (21).

In accordance with previous study conducted by (4) which stated that there was no correlation between self-efficacy and efforts to prevent cervical cancer in reproductive-aged women in Kenjeran Community Health Center Surabaya.

4.3 The relationship between interpersonal factors with cervical cancer prevention behavior

Distensi uterus berlebih terjadi pada kasus ibu hamil The results showed that there was a significant relationship between interpersonal factors and cervical cancer prevention behaviors with low strength relationship and positive direction relationship. The Health Promotion Model theory stated that family, peers, and health care providers were important sources of interpersonal influence which can increase or decrease the commitment and involvement in health promotion behavior (15). Interpersonal influence consists of norms (expectations of others), social support (instrumental and emotional encouragement), and models (learning from other people's experiences) (12).

Most of reproductive-aged women have a high interpersonal factor in preventing cervical cancer. The high interpersonal influence in this study was the influence of health workers (doctors, nurses and midwives) who suggested early detection of cervical cancer, supported prevention of cervical cancer, and provided complete information regarding IVA or pap smear examination. There were many family members who have not had an AVI or pap smear. The main reason why women have cancer screening tests was because of their past health experiences, whether personal, family or friends (23).

Based on the results of the study, most of reproductive-aged women had high interpersonal factors and had good cervical cancer prevention behavior. Characteristics of respondents in performing cervical cancer prevention behavior were educated and employment status, most of the reproductive-aged women who graduate from senior high school education and work as housewives. Reproductive-aged women who work as housewives and had houses close each other made the socialization between neighbors and peers through Maternal and Child Health Services activities, PKK community, etc increase. In addition, because they got support from health workers to prevent cervical cancer. WUS who followed cervical cancer socialization and AVI tests, WUS became interested in conducting AVI tests. After attending the socialization so that they became more aware of the importance of early detection of cervical cancer and the benefits gained when doing AVI tests (3).

Disease risk perception was a determinant of health behavior, although the nature of the relationship between risk perception and health behavior may depend on various types of risk perception and the accuracy of that perception (24). Most of reproductive-aged women had 2 times pregnant of parity status. The tendency for women to suffer from cervical cancer was greater in multi and grandemultigravida (22). If they have a high interpersonal factors and good cervical cancer prevention behavior, then it could reduce the risk factors for cervical cancer.

Reproductive-aged women who have high interpersonal factors and lack of cervical cancer prevention behavior, because there are family members, neighbors, or friends who did not do any AVI test or pap smear, so that most reproductive-aged women also did not do secondary prevention in the form of AVI examination or PAP smear. The main reason given why women have cancer screening tests was because of past health experiences, whether personal, family or friends (23).

In line with the study which conducted by (25) stated that there was a relationship between interpersonal factors and efforts to prevent cervical cancer in reproductive-aged women in the working area of the Lamongan community health center. However, the research conducted by (26) stated that there was no relationship between interpersonal influence and prevention of breast cancer. In this study, interpersonal influences did not significantly affect one's commitment to prevent breast cancer.

\section{CONCLUSION}

Perceived barriers in reproductive-aged women with negative results would inhibit the cervical cancer prevention behavior. Good cervical cancer prevention behavior, supported by the surrounding people, especially health workers. Self efficacy was not proven to determine the behavior of cervical cancer prevention in reproductive-aged women. Most of reproductive-aged women had weak self efficacy, but they had good cervical cancer prevention behavior.

The higher the interpersonal factors, the better the behavior of reproductive-aged women in cervical cancer prevention. Family, peers, and health care providers were very influential in improving health behavior. Health workers were expected to provide a more detailed explanation of the AVI examination procedure or pap smears so that the reproductiveaged women were not ashamed to do an AVI test and could improve their encouragement or advice to prevent cervical cancer.

\section{ACKNOWLEDGEMENT}

Praise and gratitude for Allah SWT, thanks to His grace and guidance so we can complete this research. Let me express my sincere thanks with sincere heart to the Faculty of Nursing Universitas Airlangga for 
providing the opportunity to learn and get lots of knowledge, the advisors for the guidance and advices, the head of the Bakesbangpol, the Health Service Department, and the Pacarkeling Community Health Center which have given permission to conduct this research, midwives of Pacarkeling community health center for their information and assistance, as well as cadres and reproductive-aged women in Pacarkembang village who were willing to become research respondents.

\section{DAFTAR PUSTAKA}

1. Kementerian Kesehatan RI. Buletin Jendela. Data dan Informasi Kesehatan. 2015. 1-44 p.

2. Nugrahani RR, Budihastuti UR, Pamungakasari EP. Health Belief Model on the Factors Associated with the Use of HPV Vaccine for the Prevention of Cervical Cancer among Women in Kediri, East Java. J Epidemiol Public Heal. 2017;02(01):70-81.

3. Sahr LA, Kusumaningrum TAI. Persepsi dan Perilaku Wanita Usia Subur dalam Melakukan Tes Inspeksi Visual Asam Asetat. J Promosi Kesehat Indones. 2018;13(2):114.

4. Armini NKA, Kurnia ID, Hikmah FL. Faktor Personal, Self Efficacy dan Upaya Pencegahan Kanker Serviks pada Perempuan Usia Produktif. J Ners Unair. 2016;11(2):294-9.

5. Tiraki Z, Yılmaz M. Cervical Cancer Knowledge, Self-Efficacy, and Health Literacy Levels of Married Women. J Cancer Educ. 2017;33(6):1270-8.

6. Febriani CA. Faktor-Faktor yang Berhubungan dengan Deteksi Dini Kanker Leher Rahim di Kecamatan Gisting Kabupaten Tanggamus Lampung. J Kesehat. 2016;VII(Nomor 2):22837.

7. Global Cancer Observatory (GCO). Global Cancer Observatory (GCO). 2018;1-2. Available from: http://gco.iarc.fr/today/data/factsheets/popul ations/360-indonesia-fact-sheets.pdf

8. WHO. Cervical cancer. 2018. Available from: https://www.who.int/cancer/prevention/diag nosis-screening/cervical-cancer/en/

9. Bazaz M, Shahry P, Latifi SM, Araban M. Cervical Cancer Literacy in Women of Reproductive Age and Its Related Factors. J Cancer Educ. 2019;34(1):82-9.

10. Sari AP, Syahrul F. Faktor yang Berhubungan dengan Tindakan Vaksinasi HPV pada Wanita Usia Dewasa. J Berk Epidemiol. 2014;2(3):32130.

11. Kementerian Kesehatan RI. InfoDatin. Pusat Data dan Informasi Kementerian Kesehatan RI. 2015. 8 p.

12. Nursalam. Metodologi Penelitian Ilmu
Keperawatan Pendekatan Praktis Edisi 4. Lestari PP, editor. Jakarta: Salemba Medika; 2017. 454 p.

13. Amanda SR. Analisis Persepsi Manfaat, Persepsi Hambatan dengan Pemilihan Kontrasepsi AKDR pada Wanita Pasangan Usia Subur Berdasarkan Teori Health Promotion Model di Puskesmas Mulyorejo Surabaya. Universitas Airlangga; 2016.

14. Prastiwi AW. Hubungan Faktor Interpersonal, Situasional, dengan Upaya Pencegahan Kanker Serviks pada Perempuan Usia Produktif. Universitas Airlangga; 2017.

15. Pender N. Heath Promotion Model Manual. 2011;1-19. Available from: http://hdl.handle.net/2027.42/85350

16. Depkes R. Sistem Kesehatan Nasional. Jakarta; 2009.

17. Afsah YR. Perceived Barriers of Cervical Cancer Screening Among Married Women in Minggir, Godean, Gamping Sub-Districts, Sleman District Yogyakarta. Indones J Nurs Pract. 2017;1(2):7582.

18. McMorrow L, Ludbrook A, Macdiarmid JI, Olajide D. Perceived barriers towards healthy eating and their association with fruit and vegetable consumption. J Public Heal (United Kingdom). 2017;39(2):330-8.

19. Bandura A. Self-Efficacy. Vol. 4, Encyclopedia of human behavior. New York: Academic Press. (Reprinted in H. Friedman [Ed.], Encyclopedia of mental health. San Diego: Academic Press, 1998).; 1994. 71-81 p.

20. Kim ES, Strecher VJ, Ryff CD. Purpose in life and use of preventive health care services. Proc Natl Acad Sci. 2014;111(46):16331-6.

21. Parapat FT, Setyawan H, Saraswati LD. FaktorFaktor yang Berhubungan dengan Perilaku Deteksi Dini Kanker Leher Rahim Metode Inspeksi Visual Asetat di Puskesmas Candiroto Kabupaten Temanggung. J Kesehat Masy. 2016;4(4):363-70.

22. Aziyah A, Sumarni S, Ngadiyono N. Faktor Resiko Yang Berhubungan Dengan Kejadian Kanker Servik; Studi Kasus Di Rsup Dr. Kariadi Semarang. J Ris Kesehat. 2018;6(1):20-5.

23. Torres E, Erwin DO, Treviño M, Jandorf L. Understanding factors influencing Latina women's screening behavior: A qualitative approach. Health Educ Res. 2013;28(5):772-83.

24. Ferrer RA, Klein WMP. Risk perceptions and health behavior. Curr Opin Psychol [Internet]. 2015;5:85-9. Available from: http://dx.doi.org/10.1016/j.copsyc.2015.03.01 2

25. Armini NKA, Fauziningtyas R, Prastiwi AW. 
PEDIOMATERNAL NURSING JOURNAL

Proceeding Conference INC 2018 Universitas Airlangga "Cancer Prevention." 2018.

26. Nastiti AA, Armini NKA, Ulazzuharo C. Hubungan Pengaruh Interpersonal dan Situasional dengan
Upaya Preventif pada Perempuan Penderita Kanker Payudara (Correlation Between Interpersonal and Situational Influence with Preventive Efforts in Breast Cancer Survivor). J Ners Lentera. 2018;5(2):156-68. 